\title{
Technological Capability and Internationalization of Companies in Brazil
}

\author{
Andréa Torres Barros Batinga de Mendonça ${ }^{1}$ \& Sieglinde Kindl da Cunha ${ }^{2}$ \\ ${ }^{1}$ Postgraduate Programme in Management, Federal University of Paraná, Brazil \\ 2 Postgraduate Programme in Management, Federal University of Paraná, Masters and Doctoral Program in \\ Management, Positivo University, Brazil \\ Correspondence: Andréa de Mendonça. Avenida Professor Lothario Meissner, $6322^{\circ}$ andar, Jardim Botânico, \\ City of Curitiba, State of Paraná, 80210-170, Brazil. E-mail: deatorres@gmail.com
}

Received: November 5, 2013

Accepted: December 2, 2013

Online Published: January 23, 2014

doi: 10.5539/ibr.v7n2p29

URL: http://dx.doi.org/10.5539/ibr.v7n2p29

\begin{abstract}
The global market nowadays demands even more strongly that companies should seek new sources of knowledge and develop new skills in order to become more innovative. In this context, it is clear that those companies that are more deeply involved with the international market develop more innovative types of technological capability than those which operate in the domestic market only. Thus, this paper aims to identify the similarities and/or differences in the technological capabilities of software companies in Curitiba, the capital of the state of Paraná in Brazil, with different levels of internationalization. From the case studies, a direct relationship was observed between increased international involvement and an increase in accumulated technological capabilities.
\end{abstract}

Keywords: technological capabilities, internationalization, software, Brazil

\section{Introduction}

The current economic scenario of fierce international competition, with the need to introduce technological improvements in production processes and the evolution of the economic system, have given rise to a constant concern in companies to develop strategies to improve their innovative capability (Cassiolato \& Lastres, 2000; Corazza \& Fracalanza, 2004).

Figueiredo (2005) notes the emergence of many studies examining the implications of learning processes in the technological path of firms in developing countries. The early stage, in the 1990s, was marked by new inquiries which were concerned with studying the basic proceedings of organizational learning and the sense in which learning influenced the technological accumulation of enterprises (Figueiredo, 2005). Thus, in the past two decades, studies highlighting the usefulness of "learning" and "capability" for improving the performance of companies have grown in importance (Cassiolato \& Lastres, 2000; Figueiredo, 2002; Lemos, 2000).

In this sense it is valuable to understand technological capability as a set of skills, experience and efforts which allows companies to use, adapt, improve and create technologies (Lall, 2005). Therefore, a relationship can be observed between the development of technological capabilities and increased knowledge of the market in a procedural approach, the internationalization of companies in an evolutionary perspective that is a process in which they can increase their international involvement owing to their increased knowledge of foreign markets and accumulated experience of operating in these foreign markets (Johanson \& Vahlne, 1977; Zander, 2002).

Given this context, this article aims to identify the similarities and/or differences in technological capability of software companies in Curitiba which have different levels of internationalization.

Despite the large number of models and approaches which have proliferated in both issues, this work is justified, from a theoretical point of view, by its attempt to approach issues through the development of specific models of analysis for the technological capabilities and internationalization of software companies in particular.

Moreover, the work is justified, for practical purposes, by the identification of possible differences and similarities in the levels of technological capability and internationalization and by the fact that the joint use of analytical models in the two issues can provide insights into the relationship between these two proceedings, in 
the first place observing whether or not a relationship between them exists.

Thus, policies and different strategies can be developed both by political agents in the innovation system and by managers, from the particular characteristics of the technological capabilities which companies at different levels of involvement with foreign markets develop and accumulate.

\section{Theoretical Background}

This section deals with the theoretical basis supporting the development of this work. Therefore, issues are addressed on the main aspects of the technological capability and internationalization of companies, highlighting the models found in the literature.

\subsection{Technological Capability and Brazilian Studies}

In the last two decades there has been an increasing number of studies highlighting the importance for business performance of "learning" and "ability", emphasizing international competition and the growth of globalization as factors which have caused changes in the mode of conducting an organization's business (Figueiredo, 2002).

From these perspectives, authors such as Hobday and Rush (2007) define the technological capability of an organization as the accumulation of knowledge, skills, experience and organizational base which enables the company to acquire, develop and use technology to achieve competitive advantage.

Figueiredo (2002) gives another definition, taking into account that the technological capability of the company covers the resources needed to manage improvements in production processes and organization, products, equipment and engineering projects.

The development of technological capabilities of an enterprise is thus the result of investment made by the company in response to internal and external stimuli, and interaction with other economic agents (private and public, local and foreign), these capabilities being the very intangible assets that fall into the category of knowledge assets (Lall, 1992; Savory, 2006). Several authors have proposed models of technological capabilities (Bell \& Pavitt, 1995; Dutrénit, 2004; Figueiredo, 2003; Lall, 1992).

Lall's model $(1992 ; 2005)$ assumes that the technology is analysed by means of evolutionary theory, defining technological capabilities as a set of skills, experiences and efforts which gives companies the power needed to use, adapt, improve and create technologies (Lall, 2005).

It includes three levels of complexity in the technological capabilities that companies absorb (basic, intermediate and advanced), and also considers the various functions in which capacities can be built up level by level, namely: investment capabilities, production capability and the capability to relate to the economy. These functions specify the activities related to the technological capabilities proper to each level of complexity (Lall, 1992).

Bell and Pavitt's model (1995), in turn, takes into account that technological capability is the ability to generate and manage change, and that technology cannot be regarded simply as a matter of information, but as a complex gathering of information (codified and tacit).

The central idea is to differentiate between production capability and technological capability. According to Bell and Pavitt (1995), this distinction reveals an important change over the years in the proceedings of technological accumulation in an industry: the increasing specialization and professionalization of activities involved in generating and managing technical change.

Kim's model (2005) distinguishes between the technological path and the accumulation of technological capability in companies from developing countries and in countries with industrialized economies. For this author, the technological path is related to the evolutionary direction of technological advance and, in countries catching up, the technological change is largely a process of acquiring, assimilating and improving foreign technologies. However, in industrialized countries, technology adopts a process of innovation which is fluid (Kim, 2005).

The work of Dutrénit (2004) suggests two types of capability related to accumulation activities. The strategic capability, based on the understood capability of the strategic management literature, is defined as innovative technological capability, used to distinguish an enterprise competitively, to compete on the basis of knowledge (Dutrénit, 2004). The embryonic strategic capability, in turn, is that innovative technological capability still incipient and not used to distinguish the company's competitiveness; it includes an inventory of deeper knowledge in some technical functions, technical areas or fields of expertise, which may be the basis on which to build strategic capabilities (Dutrénit, 2004). 
Three stages of building technological capabilities can be distinguished, defined according to the level of accumulation of innovative technological capabilities (basic to advanced) and the use of innovative technological capabilities (to distinguish the company's competitiveness or lack of it) (Dutrénit, 2004 ).

However, the model developed by Figueiredo (2003) was adapted from Lall (1992) and Bell and Pavitt (1995); it also marks a difference between basic and advanced levels of technological capability.

In this sense the model proposes that technological capabilities be divided into routine and innovative, placed along a continuum of various technological functions. Thus, the capability of the "routine" level refers to "technological activities carried out at a certain level of efficiency and utilization of inputs" (Figueiredo, 2003). In short, these are skills needed to make use of technologies, knowledge and organizational arrangements (Ariffin \& Figueiredo, 2004; Figueiredo, 2003).

In this model there are seven levels of capability (between innovative and routine) for the following five technological functions: 1). decision and control over the plant, 2). design engineering, 3). proceedings and production organization, 4). products, and 5). equipment. According to this author, functions 1) and 2) are examined together as "investments" (Figueiredo, 2003).

From Figueiredo's model (2003) other studies specific to various areas of industry in Brazil began to take shape, such as Tacla's (2002), on the paper and pulp segment; Figueiredo's (2005), on the telecommunication industry; Castro and Figueiredo's (2005), on a unit of Companhia Siderurgica Nacional (a national steel company); Ohba and Figueiredo's $(2007 ; 2006)$, on the pharmaceutical industry, highlighting the strategic alliances in this sector; Gonzalez and Cunha's (2010), on the soluble coffee industry; Facco and Cunha's (2009), on productive local clusters, and Miranda and Figueiredo's (2006; 2010), on the software industry.

All these studies used the proposed initial division of technological capabilities at the level of complexity of routine and at the level of innovative and proposed specific technological roles. In a recent paper published by Miranda and Figueiredo (2010), this division is made for the software industry and is understood as software engineering, products and services, and process.

In this sense, it is possible to see the importance of determining the specific functions in which technological capabilities are accumulated for each sector, since each has specific characteristics which define the trajectory in terms of the capabilities needed by companies in order to be innovative to some extent and gain a sustainable competitive advantage.

\subsection{Internationalization of Companies}

To being with, it should be noted that internationalization can be understood as a proceeding in which firms gradually increase their international involvement (Johanson \& Vahlne, 1977; Welch \& Luostarine, 1988).

One major reason, according to Welch and Luostarine (1988), for adopting a broader concept of internationalization is that in the dynamics of international trade both sides of the case, the incoming and the outgoing, have become more connected. Thus, these authors claim that it is inappropriate to restrict the concept of increasing international engagement to the prospect of outputs alone, because of this connection between the two sides.

What is currently noticeable is the rapid internationalization of business, and its greater quantity. Hence, it is important to be aware that businesses are becoming international in different ways, often using a combination of entry and exit strategies (Axinn \& Matthyssens, 2001).

It is important to stress, in the view of Dib and Carneiro (2006), that theories of internationalization developed by authors of different theoretical approaches can be classified into two lines of research: the approach based on economic criteria and that based on behavioral evolution.

In the approach based on economic criteria there prevails the rational provision of solutions for issues of the process of internationalization, trying to find ways to adopt decisions which maximize economic returns (Dib \& Carneiro, 2006).

According to Buckley and Hashai (2005), the focus of scholars taking the economic approach lies in the benefits derived from the internalization of activities outside the company for the sake of international expansion. According to these authors, in this approach firms choose how to serve the foreign market by evaluating the costs of various transactions and selecting the one which incurs the lowest overall costs (Buckley \& Hashai, 2005).

This perspective is taken by the relevant theories as shown in Table 1. 
Table 1. Summary of internationalization economic approach theories

\begin{tabular}{|c|c|}
\hline THEORIES & RELEVANT ASPECTS \\
\hline $\begin{array}{l}\text { Cycle } \\
\text { Theory }\end{array}$ & $\begin{array}{l}\text { Created by Vernon }(1966 ; 1979) \text { : according to the hypothesis of the product cycle, a company which creates foreign } \\
\text { production facilities typically does so on the basis of some real or imagined monopolistic advantage. The hypothesis } \\
\text { of the product cycle begins with the assumption that the stimulus to innovation is usually provided by a threat or } \\
\text { promise in the market. }\end{array}$ \\
\hline Market Power Theory & $\begin{array}{l}\text { Hymer (1983) bases his theory on the reduction of competition, in the sense that it forces the company to continually } \\
\text { reinvest its profits and expand its market in order to save this market. In this sense, the author concludes, market } \\
\text { forces cause the internationalization of enterprises and capital. }\end{array}$ \\
\hline $\begin{array}{l}\text { Internalization } \\
\text { Theory }\end{array}$ & $\begin{array}{l}\text { Revised by Buckley and Casson }(1998,2009) \text { : it says that internalization occurs when a company expects that } \\
\text { activities will be more profitable when they are under common control, i.e., this strategy enables the company to } \\
\text { minimize transaction costs by further exploring the capabilities underused in the company (such as management and } \\
\text { technological skills) which are superior to those of local competitors (Buckley \& Hashai, 2005; Casson, Dark \& } \\
\text { Gulamhussen, 2009). }\end{array}$ \\
\hline Ecletic & $\begin{array}{l}\text { The eclectic paradigm is a simple yet profound construct, which states that the extent, geographical and industrial, of } \\
\text { industrial production composition made by foreign multinational companies is determined by the interaction of three }\end{array}$ \\
\hline Paradigm & $\begin{array}{l}\text { sets of independent variables, which themselves constitute the components of three underparadigms. These elements } \\
\text { are what is commonly known as OLI (Ownership, Location and Internalization) (Dunning, 1980, 2000, 2001). }\end{array}$ \\
\hline
\end{tabular}

Source: their authors.

The approach of internationalization based on the evolution of behaviour and the studies of exportation give a focus to the proceeding from the attitudes, perceptions and behaviours of decision makers who seek to reduce risks in deciding where and how to expand, and recognize the importance of learning and the accumulation of knowledge in enterprises (Blomstermo, Eriksson, \& Sharma, 2004; Dib \& Carneiro, 2006).

Thus, according to Blomstermo et al. (2004), we obtain a better comprehension of companies' internationalization process from a better understanding of the learning process of global companies and the individual factors that affect learning and the transfer of this knowledge from one country to another.

This perspective is taken by the relevant theories as shown in Table 2 .

Table 2. Summary of internationalization behavior approach theories

\begin{tabular}{ll}
\hline THEORIES & RELEVANT ASPECTS \\
\hline & The Uppsala model, according to Johanson and Vahlne (1977; S 2009), shows that the lack of knowledge is a \\
major obstacle to the development of international operations and the necessary knowledge can be acquired \\
mainly through operations abroad. This is ensured by two guidelines of internationalization: a) "increase of the \\
company's involvement in a foreign country and b) "successive establishment of operations in new countries" \\
(Johanson \& Vahlne, 1977, p. 23). \\
I-models have been identified in the work of Andersen (1993) and explain internationalization from an \\
innovation-related perspective. Thus, according to the work of Andersen (1993) and Leonidou and Katsiki \\
(1996), several models related to innovation based on stages of evolution can be found in the literature: Bilkey \\
and Tesar, Cavusgil, Czinkota, Reid, Barrett and Wilkinson, Moon and Lee, Lim and others, Rao and Naidu \\
and Crick (Andersen, 1993; Leonidou \& Katsikeas, 1996). \\
I-Models (Innovation) \\
$\begin{array}{l}\text { Lan and Wu (2010) justify the use of entrepreneurial orientation as a way of representing the style and specific } \\
\text { method of strategic direction, decision making and decision implementation of a company. A new international } \\
\text { company in the design of Oviatt and McDougall (2005) is one which seeks, at first, to obtain a significant } \\
\text { competitive advantage from the use of resources and result sales in several countries. }\end{array}$ \\
Intrepreneurial \\
$\begin{array}{l}\text { Authors who depend on this theory argue that the internationalization of a company's success in entering } \\
\text { international markets depends more on its position in a network and relationships within the current markets, } \\
\text { than the characteristics of the culture and the market (Dib \& Carneiro, 2006; Tseng \& Kuo, 2008). }\end{array}$ \\
$\begin{array}{l}\text { Network } \\
\text { Theory }\end{array}$ \\
\hline
\end{tabular}


Export model of Brazilian companies
According to Kraus (2006), from the literature he reviewed, it is noted that the change from an export process to a more committed level implies that the company takes long-term risks and that the bonds created after establishing a subsidiary are hard to break. Kraus (2006) divides the export stages of Brazilian companies into pre-export, sporadic exporter and compromised involvement.

Source: their authors.

\section{Method}

To achieve our objective of identifying the similarities and/or differences in technological capabilities in software companies in Curitiba which have different levels of internationalization, a study of the qualitative approach was developed, since material and interpretable practices were employed to make the relevant features visible by a "multiple cases study" (Denzin \& Lincoln, 2006).

The work may also be characterized as exploratory-descriptive, since it aims to explore the relationship between technological capability and the internationalization of enterprises (Babbie, 2007), to describe the situations and phenomena observed (Babbie, 2007; Richardson, 2007) in the levels of technological capability and internationalization of the firms surveyed, and to identify the similarities and differences between companies.

Firms were chosen according to the level of internationalization, as developed from the models of Coviello and Munro (1997) and Kraus (2006). These are shown in Table 3 below.

Table 3. Internationalization proceedings of software companies

\begin{tabular}{ll}
\hline Company Orientation & Characteristics \\
\hline Pre-engagement & Domestic market oriented \\
Company A & Intention to internationalize \\
Passive/ active Engagement & Fair attendance \\
Company B & Real contact with international agents \\
& Direct Sales to markets with little psychic distance \\
& Performance in several markets \\
Committed/ Engaged & Adequate to consumer habits \\
Company C & Specific product development for the international market \\
& Business opportunities as openings of sales office \\
\hline
\end{tabular}

Source: Adapted from Coviello; Munro (1997) and Kraus (2006) and research data.

Thus, the researched companies were chosen from the list of companies participating in the cluster of software providers in Curitiba, with advice from people involved in the software sector, taking into account the characteristics of internationalization as a determinant for the selection of the three cases under study.

It is also noteworthy that an appropriate model was developed for analysis and classification to identify and describe the technological capabilities of enterprises from Miranda and Figueiredo's specific studies $(2006 ; 2010)$ of the software industry and taking into account the specificities found in the software sector of Curitiba. The descriptive model includes three technology functions previously defined by Miranda and Figueiredo (2006; 2010) and three levels of technological capability: routine, intermediate and innovative. These functions and levels can be observed in the following table. 
Table 4. Descriptive model for the technological capabilities for software companies

\begin{tabular}{|c|c|c|c|}
\hline \multirow{2}{*}{ Level } & \multicolumn{3}{|c|}{ Technological Function } \\
\hline & Software Engeneering & Products/Services & Processes \\
\hline Routine & $\begin{array}{l}\text { - Software engineering tools } \\
\text { used in an incipient way; } \\
\text { - Formalization of the nascent } \\
\text { practice of software engineering; } \\
\text { - Centralized Back-up of the } \\
\text { source-code; } \\
\text { - Ad hoc engineering practices } \\
\text { of software. }\end{array}$ & $\begin{array}{l}\text { - Replications of functional and } \\
\text { technical specifications for certain } \\
\text { customers; } \\
\text { - Maintenance of existing } \\
\text { solutions; } \\
\text { - Re-engineering of existing } \\
\text { products. }\end{array}$ & $\begin{array}{l}\text { - Non-formalized operational } \\
\text { processes; } \\
\text { - Different processes } \\
\text { followed in each project. }\end{array}$ \\
\hline
\end{tabular}

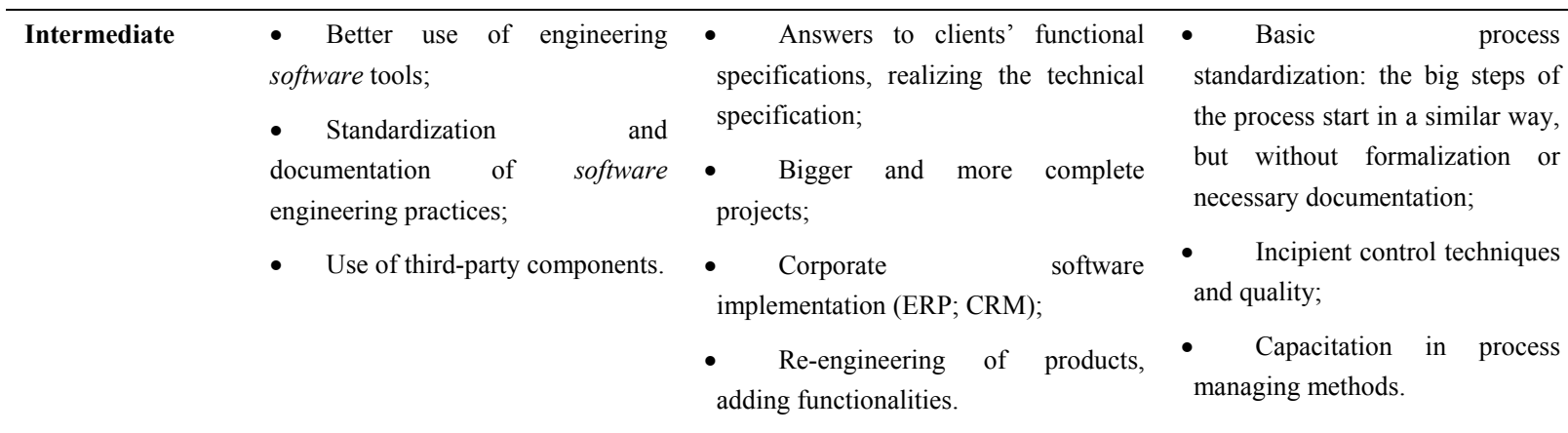

\begin{tabular}{|c|c|c|c|}
\hline Innov & $\begin{array}{l}\text { - Integration of software } \\
\text { engineering tools; } \\
\text { - Creation and control of } \\
\text { automated version; } \\
\text { - Own software engineering } \\
\text { tools; } \\
\text { - Geographically distant teams; } \\
\text { - Integration with other } \\
\text { knowledge area tools. }\end{array}$ & $\begin{array}{l}\text { - Solutions developed with } \\
\text { specific knowledge of the client's } \\
\text { business; } \\
\text { - Configuration } \\
\text { personalization of corporate } \\
\text { software programs (ERP, CRM); } \\
\text { - Complete solutions with } \\
\text { integration and personalization of } \\
\text { corporate software programs; } \\
\text { - Methods to assess clients' } \\
\text { satisfaction. }\end{array}$ & $\begin{array}{l}\text { - Strategic quality } \\
\text { management; } \\
\text { - CMMI certification; } \\
\text { - Adaptation of the } \\
\text { structure of the company to the } \\
\text { process; } \\
\text { - Process controlled by } \\
\text { quality metrics; } \\
\text { - Automation of key stages } \\
\text { of the process, as unit tests and } \\
\text { version control; }\end{array}$ \\
\hline
\end{tabular}

- Constant Process update.

Source: Adapted from Miranda and Figueiredo $(2006 ; 2010)$ and research data.

Data were collected through a total of 7 semi structured interviews with representatives of three companies: a development manager of Company A; a development manager and a continuing education manager of Company $\mathrm{B}$; and a laboratory consultant for solutions development, an international Marketing analyst, an information analyst (the company's quality system) and a member of staff in charge of the sector for analyzing and improving business proceedings in Company C. Each interview lasted an average of 60 minutes and each was taped and later transcribed into text editing software. Besides the material company interviews, such as the presentation of programs within the company, report manuals and customer satisfaction forms were analyzed to collect additional information.

All the data collected were further analyzed, using techniques of content analysis in order to identify the relevant information for each company in each category of analysis to achieve the specific objectives of the present work. This analysis, which did not rely on help from software, was held through certain categories of analysis in the construction of the interview script and divided into four topics: a) identification of the company and interviewee; b) the innovation system; c) functioning technological capabilities; d) the company's internationalization. 
A comparative table of cases was also made possible by a content analysis of each interview and each company with respect to those items described above that were part of the interview script.

\section{Description of the Cases}

This topic covers the description of the companies surveyed, reporting their main characteristics and trajectory in the market, besides their main activities in the work with software and their contacts with the international market.

\subsection{Case A}

Case A is characterized as a company which maintains no ties with foreign markets, serving only the domestic market, both in Curitiba and in other states of Brazil, as will be seen below. So this company falls into the sample companies category of a pre-engagement company with only domestic operations.

It was created in 2004 by the research participant manager with other employees who has worked in software development. The development manager graduated in business administration and has been working with IT since 1992.

Regarding activities, the company develops software for personal use and for customers, such as the X-ERP, which is a software program for business management. The company also makes adjustments for their own use. Furthermore, the company develops package-software - the X-ERP can be considered as such-once the software is ready, and is subject to change. In this product, if the client wants a new report or has a new need, the company will provide the necessary changes.

The company's main market is the national one, Curitiba in particular, mostly for small and medium-sized enterprises. But the company has customers in other states, such as Pernambuco, in the city of Caruaru, and other states such as Santa Catarina, Sao Paulo, Espírito Santo, Bahia, Mato Grosso e Mato Grosso do Sul.

Although the company is not currently maintaining any kind of international relationship, it tried making contact with SOFTEX (Association for Promotion of Brazilian Software Excellence), but never went ahead with action to internationalize. The manager says that he prefers to make the software more stable in the domestic market before moving on to the international market. At present, the company is not taking any kind of action to engage with foreign markets, but eventually plans to participate in fairs and send emails to international associations.

\subsection{Case B}

This company belongs to the category defined by Coviello and Munro (1997) and Kraus (2006) as having passive/active involvement, but a recent internationalization process and Case B is part of the Software Cluster in Curitiba, acting as an institution which integrates teaching, research, and business development in IT. It was founded in 1992 and in the same year was designated as the Regional Centre of SOFTEX.

Up to now the company's history has been marked by some important events, such as the creation and coordination of SOFTEX's office in Europe in 1996, the opening of its headquarters in Curitiba's Software Park in 1999, the receiving of the Innovation Research Award 2004 in the category Research Institution Award and the Trophy Award from FINEP (financing of studies and projects) for Expression and Technological Innovation in 2005. In 2009 the company also reached certification CMMI level 3, which provided organizational innovations such as the formalization of proceedings.

As the company is characterized by having two different audiences, one which is interested in the software which it develops and another which hires it for training and consultation, including consultants for the implementation of MPS $\mathrm{Br}$, it has various contacts in the international market. (MPS $\mathrm{Br}$ is the process improvement of the Brazilian software, compatible with CMMI.)

The company made its first contacts with the international market when it acted as an event organizer. It should be noted that this happened even before the company had a well-structured software development sector, with many projects.

In the area of software development, it is sometimes difficult to determine when and how the steps occur, because, according to the manager of continuing education:

"It is like this: we have many projects using IT legal resources, and hence they are developed by the technology team. So our partners, such as Siemens, often developed international projects using the team. Our company, on that account, has developed several projects in partnership, as with Siemens Mexico, for example."

According to the development manager, the company has most recently completed projects with Angola in 
Luanda, Africa (2007), and is currently developing a project for a company located in Manaus, which is being internationalized to Romania. He said that a Case B company is helping this company in Manaus to adopt a broader system for them to use in Romania.

\subsection{Case C}

Company C was founded in 1992 at first under a different name from its present one. Since then, the company has been involved in software development activities. In 1995, realizing market opportunities, it also started to offer services such as Internet provider.

In 1998 the company was certified with ISO 9001, as part of its concern to maintain quality and productivity. From this point it expanded until it was invited to develop public health systems and a project for RFID (Radio Frequency Identification) to monitor roads.

The year 2001 marked the company as a pioneer in launching systems for mobile computing with Java/IBM technology and in 2003 the company also started operating in the area of Software Quality Assurance (SQA), in which it developed tools for automated banking. In 2009, the company decided to internationalize all business units and achieved Level 3 CMMI. Currently the company operates in three major areas:

- Solutions Development Laboratory: consulting, P\&D services, integration systems, business proceedings modelling (BPM), among other services;

- Software Factory: web development, self-service solutions, mobile application development, embedded software development, software testing, quality assurance, database development, among others;

- IT Professional Services: systems support, systems support development, technical support, outsourcing, allocation of skilled professionals, and others.

The internationalization of the company was started by one of three business units and is now spreading to the others. Thus, according to the consultant interviewed, the trend is that the $70 / 30$ ratio should change and become more balanced, considering the increased participation of foreign markets in the company's revenue.

Currently the company serves five customers abroad and operates with the international market in two areas, factory software and IT professionals. As a software factory, for example, the company has a client based in Switzerland. Another service related to the outsourcing of IT professionals is for a client who represents a US satellite radio station. Today, the international market represents $30 \%$ of company sales.

\section{Similarities and Differences between Cases}

With a view to identifying the main differences and similarities in the cases studied, in relation to the levels of technological capability achieved by the companies and their different levels of internationalization, Table 5 contains a summary of the characteristics of the companies regarding their technology functions and levels of technological capability.

Table 5. Summary of similarities and differences between companies A, B and C

\begin{tabular}{|c|c|c|c|}
\hline \multirow{2}{*}{$\begin{array}{l}\text { Technological } \\
\text { Capability Level }\end{array}$} & \multicolumn{3}{|c|}{ Technological Functions } \\
\hline & Software Engineering & Products/Services & Proceedings \\
\hline Routine & $\begin{array}{l}\text { Only case A, not internationalized, has } \\
\text { characteristics at this level for this } \\
\text { function, making use of tools and } \\
\text { practices unevenly. Firms in Cases B } \\
\text { and C differ from that of Company A } \\
\text { because they have already exceeded } \\
\text { this level of technological capability. }\end{array}$ & $\begin{array}{l}\text { Only case A, not present in the } \\
\text { international market, has } \\
\text { features at this level of } \\
\text { technological capability, } \\
\text { differing from the others, } \\
\text { which have already gone } \\
\text { beyond them. }\end{array}$ & $\begin{array}{l}\text { As in other functions, only case A has the } \\
\text { features at this level of technological } \\
\text { capability. } \\
\text { It does not have all the formalized } \\
\text { proceedings, while the others have a more } \\
\text { complete formalization of their proceedings. }\end{array}$ \\
\hline Intermediate & $\begin{array}{l}\text { At this level are Companies A and B, } \\
\text { which have an active involvement with } \\
\text { the international market and have } \\
\text { similar characteristics because they } \\
\text { make use of third party tools. }\end{array}$ & $\begin{array}{l}\text { At this level are Companies B } \\
\text { and C. They are alike in } \\
\text { considering and responding to } \\
\text { customers' specifications. }\end{array}$ & $\begin{array}{l}\text { In this technological capability is case A. The } \\
\text { standardization of its proceedings, reflecting } \\
\text { its low formalization, is still basic, while } \\
\text { other companies have a more complete } \\
\text { standardization. }\end{array}$ \\
\hline
\end{tabular}


At this level Companies $\mathrm{B}$ and $\mathrm{C}$, which have committed involvement with the international market, also have similar characteristics, since they promote tools integration. Company $\mathrm{C}$ has, furthermore, more innovative features than Company B, since it also uses its own tools and of others, seeks continuous improvement of its proceedings and integrates tools from different areas. Company A has no innovative features for this function.
At this level are cases B and C, committed to At this level also cases $\mathrm{B}$ and the international market. The main similarity $\mathrm{C}$, both having contact with between them at this level is the CMMI the international market, have Level 3 certification, indicating a high degree similar characteristics. But case $\mathrm{C}$ has an extra feature, in having created its own methodology to identify customer satisfaction. of formalization, which differentiates them from Company A, which lacks it. Other similarities between Companies $\mathrm{B}$ and which differ from Company A are the strategic concern with quality management and controlled proceedings for quality metrics.

Source: research data, the authors.

Comparing each level and each function, it can be observed that, regarding the function "software engineering", only Company A, which has no involvement with the international market, is at routine level. So the main difference between this and the others is the irregular use of tools and software engineering practices.

At the intermediate level, the only similarity between Companies A and B is the fact that they use tools from a third party. Although Company $\mathrm{C}$ also makes use of third party tools, it also develops its own tools and promotes their integration, an aspect which raises it to the innovative level of this technological function and distinguishes it from the others.

Thus, firms in cases B and C, which have involvement (active and engaged, respectively) with the international market, have higher levels of technological capability, going from intermediary to innovative. In this case, the main difference between the two is the fact that Company $\mathrm{C}$ promotes integration between tools from different areas within the organization, besides using tools developed by themselves and others.

In this sense, there was a greater similarity between the companies which have contact with the international market. Their practices of software engineering are more integrated and diversified, while Company A, without contact with the international market, has no such diversification and consistent use of tools.

The analysis of this technological function enables us to observe possible relationships between the development of technological capabilities and the internationalization of the company. As noted by Lall (1992), not only do internal inputs influence the development of technological capability, but external inputs are also valuable in this process, in addition to the accumulation of skill and knowledge previously acquired.

In relation to "products/services" only Company A shows a routine level, since it is not involved with the international market. It is also noteworthy that Company A is characterized only at this level for this technological function.

The two other cases, B and C, feature between the intermediate level and innovative. They can be considered similar and respond to customers' specifications. This feature also applies to Company A. However, because it has a platform product which is adapted to other customers, the level of innovation can be considered minor, whereas the others get their services "from the beginning".

Regarding the innovative level, Company $\mathrm{C}$ differs from the others, including Company $\mathrm{B}$, which is also at this level, because it has a methodology to identify customer satisfaction while the others do not. This concern is especially relevant when the company deals with customers who are geographically dispersed and culturally diverse, causing the company to be featured on an innovative level.

Yet regarding the function "process", what is perceived here, as well as in previous functions, is the presence of Company A alone, still at the routine level of technological capability. This characterization is due to its not having formalized proceedings, unlike the others.

Companies $\mathrm{B}$ and $\mathrm{C}$ have higher levels of formalization, hence they have a CMMI Level 3 software quality certification. This feature is still the main similarity between Companies B and C, which are at the innovative level of technological capability for this function proceeding. There are also similarities between Companies B and $\mathrm{C}$, which are not shared by Company $\mathrm{A}$, such as the strategic concern with quality management and proceedings controlled by quality metrics. These characteristics are reflected in the CMMI certification achieved 
by the companies. Such certification may also be a reflection of the internationalization process which Companies $\mathrm{B}$ and $\mathrm{C}$ underwent. Both perform on strongly competitive fields in the international market and need to have quality certificates in their products and proceedings so that they can compete equally with foreign companies and ensure quality products and services to consumers.

It may be noted, as stated by Lall (2005), that Companies B and C, regarding the function process in particular, invested in more complete learning processes and in the search for external factors that influenced the development of their technologic ability. This is demonstrated by investments in international certification, which give visibility not only in the domestic market.

This search for external sources of knowledge takes shape, as Kim notes (2005), as one of the most important factors in learning, in particular for countries engaged in catching up. Thus, Companies B and C reveal the demand in the international market for new sources of knowledge which has fostered the innovative advance in more than one of the technological functions.

Advances in the development of technological capabilities by companies which operate in the international market is also highlighted by Zander (2002). The author states that this contact with the international market involves a gradual increase in the accumulation of experience.

Another fact to be considered is the integration with the innovation sector system in which, according to Dutrénit (2004), the processes of technological learning and capacity building are influenced by technological innovation systems and the type of relationships formed among agents in a specific context. The idea, is that within a region and place, networks are created between companies, universities, customers, suppliers and other agents which play an important role in the innovation process (Dutrénit, 2004).

Analysis of the companies corroborates these considerations, since Companies B and C are active and always in contact with other agents and actions performed within the sector system of innovation software, whereas, as seen in the item description cases, Company A does not participate in the actions of the innovation system.

In this sense, adds Krätke (2010), the interconnection of knowledge resources occurs on different spatial scales simultaneously: on the one hand, regional clusters and inter-organizational networks within a region can facilitate knowledge flows between organizations; on the other, supra-regional and global relations may also be important in gaining access to external knowledge sources.

For final illustration see Figure 1, which shows the companies' ranking according to technological capacity.

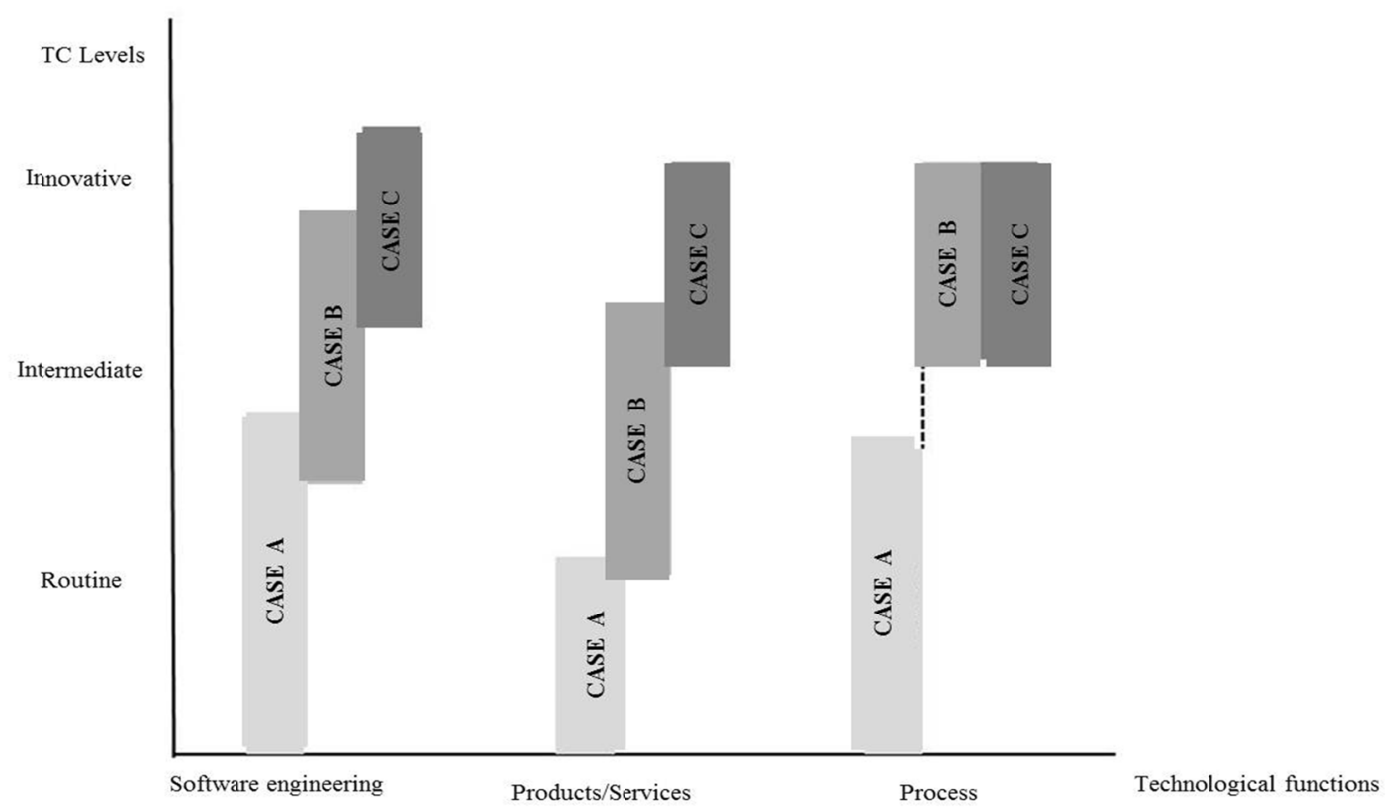

Figure 1. Comparison of levels of technological capability in each function

Source: research data, the authors. 
Given these arguments and analysis, Lall (2005) adds that participation in global competition encourages the development of technological capabilities, and direct contact with export markets is a good source of technological information.

\section{Discussion and Conclusions}

In the face of the fierce competition that permeates the economy, no longer a national issue, but now present and integral to the amalgamated global markets, organizations have sought to improve themselves and develop their innovation capabilities in order to remain competitive and reach new markets.

Therefore we find a positive effect of globalization in the pursuit of developed technological capability by organizations and in the new ways found to internationalize. Thus, it is emphasized that with increasing market knowledge and experience, companies are more likely to reach business outside their home environment and are facing new demands for capability and improvements in their technologies and human resources, as well as innovation in their products and services.

The analysis of the main similarities and differences in levels of technological capability among companies with different degrees of internationalization also considered the technological functions specified for the study and their levels of technological capability, in which the companies at each level were pointed out.

Overall, we noticed a difference between Company A and the other two companies. Case A, which has no relationship with the international market, presented a lower level of technological capability, focusing primarily on routine and intermediate levels.

Company $\mathrm{C}$ stood out from the others because it had made a breakthrough in all technological functions, even though Company B also appears as an innovator in the function processes since it also has Level 3 CMMI certification. However in the functions of software engineering and products and services, Company B is still ranked at the intermediate level.

Besides a greater commitment to the international market, Companies A and B are also more involved with the agents and institutions of the innovation system sector, distinguishing themselves from Company A, which described itself as not getting directly involved with the Software Local Productive Arrangement in Curitiba.

It is understood, as noted by Kim (2005), that the learning process may be influenced by factors which relate to the environment and technology market. Hence, the author adds to this understanding that the international community setting is perhaps the most important source of learning for developing countries or countries in the process of catching up; the companies from such countries are in this category.

Therefore, for many companies, to expand internationally requires a gradual increase in the commitment to foreign markets and know-how in operation experience in a particular foreign environment (Zander, 2002).

The study contributes to our understanding of the way that companies develop their technological capabilities when they are at different levels of involvement with the international market, from those with no commitment to those involved to a greater or lesser extent. Among the companies surveyed it was noted that global companies have higher levels of technological capability. That is, the search for innovations and improvements in their processes and product quality to reach levels of international demand is greater in those companies operating in foreign markets.

Having drawn attention to the importance of international action to develop more innovative technological capabilities, we realize that the three companies fit this understanding. But it is worth noting that some specific issues were not covered in this study and it is important that future studies should tackle them.

Besides a greater commitment to the international market, another construct is targeted at research as a possible influence on the levels of technological capability of enterprises; that is, the most innovative companies are involved with local productive arrangements, while the firm with lower technological capability was stated not to be directly involved with the Software Local Productive Arrangement in Curitiba.

Thus, the question is, what influences set up a network of cooperation and partnership at the level of technological capability in enterprise? To answer this question, a continuation of this study is suggested, to evaluate the influence of including companies in production arrangements for building technological capability.

It should be added that it is not only the level of internationalization that can influence the level of technological capability achieved by enterprises. This aspect is a limitation of this study: since it is a multiple case study, one cannot make general inferences about this relationship (internationalization-technological capability).

Given the contributions and limitations of this study, it is suggested that to deepen our understanding of the 
relationship between internationalization and technological capability, research with more case studies should be undertaken to verify the trend of the findings in this study. Research could also be conducted in different sectors of the economy and an attempt made to identify the influence of other factors in the process of accumulating technological capabilities and internationalization, such as the formation of collaborative networks and partnerships.

\section{References}

Andersen, O. (1993). On the internationalization process of firms: a critical analysis. Journal of International Business Studies, 24(2), 209-231. http://dx.doi.org/10.1057/palgrave.jibs.8490230

Ariffin, N., \& Figueruedo, P. N. (2004). Internationalization of Innovative Capabilities: Counter-evidence from the Electronics Industry in Malaysia and Brazil. Oxford Development Studies, 32(4), 559-583. http://dx.doi.org/10.1080/1360081042000293344

Axinn, C. N., \& Matthyssens, P. (2001). Limits of internationalization theories in an unlimited world. International Marketing Review, 19(5), 436-449. http://dx.doi.org/10.1108/02651330210445275

Babbie, E. (2007). The Practice of Social Research (11th ed.). Belmont: Thomson Wadsworth.

Bell, M., \& Pavitt, K. (1995). The Development of Technological Capabilities. In I. U. Haque (Ed.), Trade, Technology and International Competitiveness. Washington DC: The World Bank.

Blomstermo, A., Eriksson, K., \& Sharma, D. D. (2004). Domestic Activity and Knowledge Development in the Internationalization Process of Firms. Journal of International Entrepreneurship, 2, $239-258$. http://dx.doi.org/10.1023/B:JIEN.0000032775.53005.59

Buckley, P., \& Casson, M. (1998). Analyzing foreign market entry strategies: extending the internalization approach. Journal of International Business Studies, 29(3), 539-562. http://dx.doi.org/10.1057/palgrave.jibs.8490006

Buckley, P., \& Casson, M. C. (2009). The internalisation theory of the multinational enterprise: a review of the progress of a research agenda after 30 years. Journal of International Business Studies, online publication, $1-18$.

Buckley, P. J., \& Hashai, N. (2005). Firm configuration and internationalisation: A model. International Business Review, 14, 655-675. http://dx.doi.org/10.1016/j.ibusrev.2005.09.003

Cassiolato, J. E., \& Lastres, H. M. M. (2000). Sistemas de Inovação: Políticas e Perspectivas. Parcerias Estratégicas, 8 .

Casson, M., Dark, K., \& Gulamhussen, M. A. (2009). Extending internalisation theory: From the multinational enterprise to the knowledge-based empire. International Business Review, 18, $236-256$. http://dx.doi.org/10.1016/j.ibusrev.2008.12.005

Castro, E. C. D, \& Figueiredo, P. N. (2005). Aprendizagem Tecnológica Compensa? Implicações da Acumulação de Competências Tecnológicas para o Aprimoramento de Performance Técnicoeconômica em uma Unidade de Aciaria no Brasil (1997-2001). Revista de Administração Contemporânea (1st Special Ed.), 109-133.

Corazza, R. I., \& Fracalanza, P. S. (2004). Caminhos do pensamento neo-schumpeteriano: para além das analogias biológicas. Nova Economia, Belo Horizonte, 14(2), 127-155.

Coviello, N., \& Munro, H. (1997). Network Relationships and the Internationalisation Process of Small Software Firms. International Business Review, 6(4), 361-386. http://dx.doi.org/10.1016/S0969-5931(97)00010-3

Denzin, N. K., \& Lincoln, Y. S. (2006). O planejamento da pesquisa qualitativa: teorias e abordagens. Translation Sandra Regina Netz (2nd ed.). Artmed-Bookman.

Dib, L. A., \& Carneiro, J. (2006). Avaliação Comparativa do Escopo Descritivo e Explanatório dos Principais Modelos de Internacionalização de Empresas. In Encontro Nacional de Pós-Graduação e Pesquisa em Administração-ENANPAD, 30. Salvador, BA.

Dunning, J. H. (1980). Toward an eclectic theory of international production: some empirical tests. Journal of International Business Studies, 11(1), 9-31. http://dx.doi.org/10.1057/palgrave.jibs.8490593

Dunning, J. H. (2000). The eclectic paradigm as an envelope for economic and business theories of MNE activity. International Business Review, 9, 163-190. http://dx.doi.org/10.1016/S0969-5931(99)00035-9

Dunning, J. H. (2001). The Eclectic (OLI) Paradigm of International Production: Past, Present and Future. Int. J. of the Economics of Business, 8(2), 173-190. http://dx.doi.org/10.1080/13571510110051441 
Dutrénit, G. (2004). Building Technological Capabilities in Latecomer Firms: A Review Essay. Science, Technology \& Society, 9(2). http://dx.doi.org/10.1177/097172180400900202

Facco, C. A., \& Cunha, S. K. (2009). Internacionalização, Aprendizagem e Acumulação de Capacidades Tecnológicas. In Seminário Latino Ibero-Americano de Gestão Tecnológica, ALTEC, 13, Innovacion e Criatividad para desarollo sustenible. Cartagena.

Figueiredo, P. N. (2002). Does technological learning pay off? Inter-firm differences in technological capability-accumulation paths and operational performance improvement. Research Policy, 31, 73-94. http://dx.doi.org/10.1016/S0048-7333(01)00106-8

Figueiredo, P. N. (2003). Aprendizagem Tecnológica e Performance Competitiva. Rio de Janeiro: Ed. FGV.

Figueiredo, P. N. (2005). Acumulação tecnológica e Inovação industrial: conceitos, mensuração e evidências no Brasil. São Paulo em Perspectiva, 19(1), 54-69. http://dx.doi.org/10.1590/S0102-88392005000100005

Gonzalez, R. K., \& Cunha, S. K. (2010). Trajetória de Internacionalização e Capacidade Tecnológica da Cia. Iguaçu de Café Solúvel. In Simpósio de gestão da Inovação Tecnológica, 26, Vitória.

Hymer, S. (1983). Empresas multinacionais: a internacionalização do capital. Translation Aloísio Teixeira (2nd ed.). Rio de Janeiro: Edições Graal.

Hobday, M., \& Rush, H. (2007). Upgrading the technological capabilities of foreign transnational subsidiaries in developing countries: The case of electronics in Thailand. Research Policy, 36, 1335-1356. http://dx.doi.org/10.1016/j.respol.2007.05.004

Johanson, J., \& Vahlne, J-E. (1977). The internationalization process of the firm: a model of knowledge development and increasing foreign market commitments. Journal of International Business Studies, 8(1), 23-32. http://dx.doi.org/10.1057/palgrave.jibs.8490676

Johanson, J., \& Vahlne, J-E. (2009). The Uppsala internationalization process model revisited: from liability of foreignness to liability of outsidership. Journal of International Business Studies, online publication, 40. http://dx.doi.org/10.1057/jibs.2009.24

Kim, L. (2005). Da imitação a inovação: a dinâmica do aprendizado tecnológico da Coréia. Translation Maria Paula G. D. Rocha. São Paulo: Editora Unicamp.

Kraus, P. G. (2006). O Processo de Internacionalização das Empresas: o caso brasileiro. Revista de Negócios, $11(2), 25-47$.

Krätke, S. (2010). Regional Knowledge Networks: A Network Analysis Approach to the Interlinking of Knowledge Resources. European Urban and Regional Studies, 17(1), 83-97. http://dx.doi.org/10.1177/0969776409350794

Lall, S. (1992). Technological capabilities and industrialisation. World Development, 20(2), 165-186. http://dx.doi.org/10.1016/0305-750X(92)90097-F

Lall, S. (2005). A mudança tecnológica e a industrialização nas economias de industrialização recente da Ásia: conquistas e desafios. In Kim, L., \& Nelson, R. R. (Eds.), Tecnologia, aprendizado e inovação: as experiências das economias de industrialização recente. Campinas, SP: Editora Unicamp.

Lan, Q., \& Wu., S. (2010). An empirical study of entrepreneurial orientation and degree of internationalization of small and medium-sized Chinese manufacturing enterprises. Journal of Chinese Entrepreneurship, 2(1), 53-75. http://dx.doi.org/10.1108/17561391011019023

Lemos, C. (2000). Inovação na era do conhecimento. Parcerias Estratégicas, 8.

Leonidou, L. C., \& Katsikeas, C. S. (1996). The export development process: an integrative review of empirical models. Journal of International Business Studies, 27(3), 517-551. http://dx.doi.org/10.1057/palgrave.jibs.8490846

Miranda, E., \& Figueiredo, P. N. (2006). Quanto Tempo Levou? Taxa (Velocidade) de Acumulação Tecnológica em Empresas: Evidências da Indústria de Software no Rio de Janeiro e em São Paulo. In Simpósio de Gestão da Inovação Tecnológica, 24, Gramado, RS.

Miranda, E., \& Figueiredo, P. N. (2010). Dinâmica da acumulação de capacidades inovadoras: evidências de empresas de software no Rio de Janeiro e em São Paulo. Revista de Administração de Empresa, 50(1). http://dx.doi.org/10.1590/S0034-75902010000100007

Ohba, M., \& Figueiredo, P. N. (2007). Collaborating to compete: a search into capabilities and strategic alliances 
in the pharmaceutical industry. Journal of Technology Management \& Innovation, 2(2), 18-30.

Ohba, M., \& Figueiredo, P. N. (2006). Alianças Estratégicas e suas Implicações para a Configuração de Capacidades Tecnológicas: Evidências da Indústria Farmacêutica Multinacional. In Simpósio de Gestão da Inovação Tecnológica, 24, Gramado, RS.

Oviatt, B. M., \& Mcdougall, P. P. (2005). Toward a theory of international new ventures. Journal of International Business Studies, 36, 29-41. http://dx.doi.org/ 10.1057/palgrave.jibs.8490193

Richardson, R. J. (2007). Pesquisa social, métodos e técnicas (3rd ed.). São Paulo: Atlas.

Savory, C. (2006). Translating knowledge to build technological competence. Management Decision, 44(8), 1052-1075. http:dx.doi.org/10.1108/00251740610690612

Tacla, C. L. (2002). Acumulação de Competências Tecnológicas e os Processos Subjacentes de Aprendizagem na Indústria de Bens de Capital: O Caso da Kvaerner Pulping no Brasil. Dissertation. Escola Brasileira de Administração Pública, Fundação Getúlio Vargas-EBAP/FGV, 2002.

Tseng, C-H., \& Kuo, H-C. (2008). Internationalization and Network Strategies: Taiwanese Firms' Foreign Direct Investment in China and the USA. Journal of Asia Business Studies, 3(1), 23-32. http://dx.doi.org/10.1108/15587890880000488

Vernon, R. (1966). International investment and international trade in the product cycle. Quarterly Journal of Economics, 80, 190-207. http://dx.doi.org/10.2307/1880689

Vernon, R. (1979). The product cycle hypothesis in a new international environment. Oxford Bulletin of Economics and Statistics, 41(4), 255-267. http://dx.doi.org/10.1111/j.1468-0084.1979.mp41004002.x

Welch, L. S., \& Luostarinen, R. (1988). Internationalization: Evolution of a Concept. Journal of General Management, 14(2), 34.

Zander, I. (2002). The formation of international innovation networks in the multinational corporation: an evolutionary perspective. Industrial and Corporate Change, 11(2), 327-353. http://dx.doi.org/10.1093/icc/11.2.327

\section{Copyrights}

Copyright for this article is retained by the author(s), with first publication rights granted to the journal.

This is an open-access article distributed under the terms and conditions of the Creative Commons Attribution license (http://creativecommons.org/licenses/by/3.0/). 